\title{
Antifungal Effects of Paraquat and Glyphosate on Rhizoctonia solani (Kühn) in Potato in vitro Condition
}

\author{
José L. Arispe Vázquez ${ }^{1}$, Abiel Sánchez Arizpe ${ }^{1}$, Ma E. Galindo Cepeda ${ }^{1} \&$ Cristina Trejo Ramos ${ }^{1}$ \\ ${ }^{1}$ Departamento de Parasitología, Universidad Autónoma Agraria Antonio Narro, Calzada Antonio Narro \#1923, \\ C.P. 25315, Buenavista, Saltillo, Coahuila, México \\ Correspondence: Abiel Sánchez Arizpe, Departamento de Parasitología, Universidad Autónoma Agraria Antonio \\ Narro, Buenavista, Saltillo, Coahuila, México. E-mail: abielsanchez@hotmail.com
}

Received: November 28, 2020

Accepted: December 24, 2020 Online Published: January 4, 2021

doi:10.5539/jps.v10n1p16

URL: https://doi.org/10.5539/jps.v10n1p16

\begin{abstract}
Potato is one of the main crops worldwide. It this research, antifungal activity in vitro of paraquat and glyphosate were evaluated for Rhizoctonia solani control. $R$. solani was identified from potato tubers collected out from at open markets in Saltillo, Coahuila, Mexico. Two types of herbicides were applied: paraquat and glyphosate, at four different dosage treatments of: 10, 100, 1000 and $10000 \mu \mathrm{L}$. One $5 \mathrm{~mm}$ diameter PDA disc with $R$. solani mycelium was placed at the center of the Petri dish, with a radial registry fungal every $24 \mathrm{~h}$ for $192 \mathrm{~h}$. Pathogen was identified by morphological criteria and the data was evaluated randomly with a factorial arrangement, on which, herbicides represented factor A and dosage treatments were represented by factor B. Thus experimental design had two levels for factor A and five levels for factor B with six replications. The results were analyzed by the SAS version 9.1 statistical program, the mean separation with the Tukey test $(\mathrm{p}=0.05)$. Glyphosate achieved inhibition of $R$. solani by $35.5882 \%$ and paraquat up to $80.0399 \%$. Results reveal the importance of the need for more studies of these herbicides as fungicides. High concentrations of paraquat $(10000 \mu \mathrm{L})$ inhibits $R$. solani, and glyphosate does not affect $R$. solani mycelium development at low dosages (10 and $100 \mu \mathrm{L})$ and inhibits it at higher doses $(10000 \mu \mathrm{L})$.
\end{abstract}

Keywords: concentration, crop, fungi, herbicide, inhibition, dosage

\section{Introduction}

Potato (Solanum tuberosum L.) is one of the four crops of greater importance in the world, just after rice (Oriza sativa L.), wheat (Triticum aestivum L.) and corn (Zea mays L.), with a production of $368168914 \mathrm{t}$ in 2018 and in Mexico was $1802592 \mathrm{t}$ (FAOSTAT, 2020), however, potato will be one of the key crops in reducing hunger and food security across the globe (Hussain et al., 2018). R. solani cause widespread soil-borne diseases is responsible for causing significant economic losses in many important field and horticultural crops all over the world (Grosch et al., 2004; Elsharkawy et al., 2014). Furthermore, is responsible for potato losses of $70 \%$ (Carling et al., 1989; Wilson et al., 2007), if you take that 70\% loss, during that cicle, $1261814.4 \mathrm{t}$ was lost in Mexico and $257718239.8 \mathrm{t}$ worldwide.

Pesticides are chemical products used in agriculture to protect crops from pests (WHO, 2020). Glyphosate [ $\mathrm{N}$-(phosphonomethyl) glycine] is a broad-spectrum herbicide and the more is one of the more frequently used herbicides worldwide (Vila-Aiub et al., 2008; Duke \& Powles, 2008; Duke, 2018), in forestation, aquatic weed control and agriculture (Bórtoli et al., 2012), since its introduction in 1974 by the Monsanto company (now Bayer) with the commercial product Roundup (Woodburn, 2000). This herbicide disables, the enzyme 5-enolpyruvylsiquimato-3- synthetize phosphate, which prevents the union of metabolite phosphoenolpyruvate in the active site of the enzyme (Carrera \& Carreras, 2011; Salazar \& Aldana, 2011). Paraquat [Dichloride of N, N'-dimethyl-4, 4'-bipyridylium] is a non-selective contact herbicide, in 1969 was introduced to Mexico and to this day, despite its high toxicity, it is one of the more used compounds for the control of broadleaf and pasture weeds (Hernández \& Martinez, 2006).

R. solani Kühn (teleomorph: Thanatephorus cucumeris (Frank) Donk) is necrotrophic pathogen, with little effective resistance in crop plants (Nikraftar et al., 2013), causing diseases to a wide range of hosts, affecting aerial and subterranean parts (Agrios, 2004); additionally, it produces a significant reduction in the plants strength and the production of tuberculous in potato crops (Cedeño, 2001). $R$. solani consists of 14 anastomosis 
groups (AG 1-13 and BI), which have been divided based on hyphal anastomosis behavior, cultural morphology, host range, pathogenicity and other characters (Ogoshi, 1976; Carling et al., 1994, 1999, 2002).

$R$. solani is one of the most important soil pathogen fungi of the world, in cultivated and not cultivated soil, causing diseases in several crops as potato, beans, tomato, among others (Montealegre et al., 2003; Meza-Moller et al., 2007). Studies have shown effects of herbicides on plant pathogens in vitro, as the inhibition of growth and reproduction of the pathogen (Katan \& Eshel, 1973). Due the above mentioned, the objective of this research was to evaluate the antifungal activity of glyphosate and paraquat in vitro for $R$. solani control.

\section{Materials and Methods}

\section{Pathogen Isolation and Identification}

Potato tubers with $R$. solani (sclerotia) symptoms were collected from open markets in Saltillo, Coahuila, Mexico, $1 \mathrm{~cm}$ cuts with healthy and sclerotia and tissue, disinfected with $2 \%$ sodium hypochlorite for $5 \mathrm{~min}$, and washed two times with sterile distilled water for $5 \mathrm{~min}$. Four cuts equidistant manner in were placed in Petri dishes with PDA kept at $28 \pm 2{ }^{\circ} \mathrm{C}$. $R$. solani identification was determined following Sneh et al. (1991) keys. Purification was done through a spearhead and isolations were kept at $6 \pm 2{ }^{\circ} \mathrm{C}$.

\section{Used Herbicides}

Glyphosate and paraquat were the herbicides used in 10,100, 1000 and $10000 \mu \mathrm{L}$ concentrations, in addition, a control treatment (herbicide free) (Tab. 1).

Table 1. Herbicides and treatments in study

\begin{tabular}{lllll}
\cline { 2 - 5 } Treatments & \multicolumn{2}{c}{ Paraquat } & \multicolumn{2}{c}{ Glyphosate } \\
\hline & $\mu \mathrm{L}$ & Herbicide $(\mathrm{mL})$ & $\mu \mathrm{L}$ & Herbicide $(\mathrm{mL})$ \\
I & 10 & 0.0027 & 10 & 0.0020 \\
II & 100 & 0.0276 & 100 & 0.0245 \\
III & 1000 & 0.2762 & 1000 & 0.2450 \\
IV & 10000 & 2.7620 & 10000 & 2.4500 \\
V* & 0 & 0 & 0 & 0
\end{tabular}

$\mathrm{V}^{*}=$ Control (Herbicide free)

\section{PDA preparation with several herbicide dose levels}

Several herbicide dosage levels in PDA culture medium (200 and $300 \mathrm{~mL}$ of PDA in glyphosate and paraquat respectively), were added once the sterilized environment was set at $38 \pm 2{ }^{\circ} \mathrm{C}$, poured into Petri dish in a $20 \mathrm{~mL}$ average per plaque.

\section{Herbicide effectiveness}

Dhingra \& Sinclair (1985) food poisoning technique was used placing $5 \mathrm{~mm}$ diameter PDA discs with $R$. solani mycelium, at the center of the Petri dish with contaminated PDA, kept at a $26 \pm 2{ }^{\circ} \mathrm{C}$ for eight days.

\section{Evaluation}

Mycelial growth was measured daily with the support of a vernier pointing to the four cardinal points (N, S, E, W), during $192 \mathrm{~h}$. Data collected was evaluated randomly in a factorial arrangement, factor A for herbicides and factor B the treatments, with a two level in factor A and five levels for factor B, with six replications per treatment. Results were analyzed through the statistical computer program SAS version 9.1 (SAS Institute, 2002), and mean separation using the Tukey test $(\mathrm{p}=0.05)$.

\section{Results and Discussion}

The purified colonies showed a dark brown mycelial growth, this pathogen displayed a mature mycelium forming $90^{\circ}$ angle, branches, moderately wide and sclerotia hyphaes, characteristic of $R$. solani, results that agree with to Nicoletti et al., (1999), Abd-Elsalam et al., (2009), Meza-Moller et al., (2011), Díaz-Nájera et al., (2014), Ajayi et al., (2017) and Misawa et al., (2018). According to statistical analysis ( $<00.0001)$, with the resulting coefficient of variation of 3.5053, there is a statistical difference between herbicides used; glyphosate with a 2.73 .75 radial growth and paraquat with 0.8483 (Tab. 2), the Petri dish radio was $4.25 \mathrm{~cm}(100 \%)$, in general the glyphosate achieved $R$. solani inhibition by $35.5882 \%$ and paraquat up to $80.0399 \%$.

Paraquat and glyphosate are two of the more used herbicides in the world (James \& Krattiger, 1996), and in Mexico the glyphosate continues to be used without any restriction or repercussion (agricultural, urban and 
gardening use), among other highly dangerous herbicides (2,4-D, alachlor, atrazine, diuron, oxifluorfen and linuron). In 2013, 31,195 t of herbicides were applied in Mexico (Arellano-Aguilar \& Von, 2016). Currently, in the world, glyphosate is the active ingredient with more than 750 generic products (UITA, 2020), and in Mexico the glyphosate "faena" its cost per $1 \mathrm{~L}$ varies from $\$ 90.00$ in Colima to $\$ 325.00$ in Culiacan, Sinaloa (SNIIM, 2020).

Table 2. General mean of glyphosate and paraquat with effect on the growth of $R$. solani

\begin{tabular}{llll}
\hline Herbicide & Radial growth $(\mathbf{c m})$ & Ag & Inhibition mean $(\mathbf{c m})$ \\
\hline Glyphosate & $2.7375 \pm 2.0531$ & a & 1.5125 \\
Paraquat & $0.8483 \pm 1.6463$ & b & 3.4017 \\
\hline
\end{tabular}

$\mathrm{Ag}=$ Statistical aggrupation, equal letters are not statistically different according to Tukey test $(\mathrm{p}=0.05)$.

Table 3 shows difference among treatments; however, according to Tukey a 0.05 test, not significant, although, difference with observed on both herbicides at $10000 \mu \mathrm{L}$ resulted in a higher $R$. solani inhibition (Fig. 1). Castaño (1986) reported paraquat a low dosage $(12.5,25$ and $50 \mu \mathrm{L})$ had an inhibiting effect against $R$. solani, and glyphosate did not present an inhibiting effect. Mensin et al. (2013) reported paraquat achieved mycelium growth inhibition for nematophagous fungi Arthrobotrys oligospora (80\%), A. conoides (100\%), A. musiformis $(100 \%)$ and $A$. thaumasium $(100 \%)$ at the lowest evaluated concentration $(575 \mathrm{mg} / \mathrm{L})$. The fungal growth inhibition by glyphosate was due probably to the blocking of enzyme 5-enolpyruvylshikimate-3-phosphate (EPSPS) in the shikimic acid pathway that affect the amino acid synthesis (Franz et al., 1997), and paraquat has a marked effect on the growth rate (Wilkinson \& Lucas, I969a), respiration rate (Wilkinson \& Lucas, 1969b), spore germination (Wilkinson \& Lucas, I969c) and sporulation (Gareth \& Williams, I97I).

In this research, higher dosages gave better results $(10000 \mu \mathrm{L})$, results obtained are opposed those to Vargas et al. (2002) who reported the lowest glyphosate dosage accomplishing inhibition of $R$. solani growth. $(2.500 \mathrm{mg} / \mathrm{L})$ and $300 \mathrm{mg} / \mathrm{L}$ (highest dosage) concentration, which had no effect on $R$. solani growth. Harikrishnan \& Yang (2001) found no negative effect of glyphosate on vegetative growth of several $R$. solani isolates and anastomosis groups, however, inert ingredients in several formulations are suggested to be responsible of effect of glyphosate in the inhibiting mycelial growth and spore germination (Morjan et al., 2002).

Table 3. Data of glyphosate and paraquat treatments against $R$. solani

\begin{tabular}{llllll}
\hline Herbicide & Treatment & Rep & \multicolumn{1}{c}{ Mean } & Standard deviation & Ag \\
\hline Glyphosate & 1 & 6 & 4.07142857 & 0.02249339 & $\mathrm{a}$ \\
& 2 & 6 & 4.08000000 & 0.02091650 & $\mathrm{a}$ \\
& 3 & 6 & 1.49583333 & 0.14527273 & $\mathrm{a}$ \\
& 4 & 6 & $0.01666667 * *$ & 0.03027650 & $\mathrm{a}$ \\
Paraquat & 5 & 6 & 4.02500000 & 0.06892024 & $\mathrm{a}$ \\
& 1 & 6 & 0.11666667 & 0.10206207 & $\mathrm{a}$ \\
& 2 & 6 & 0.01250000 & 0.03061862 & $\mathrm{a}$ \\
& 3 & 6 & 0.02083333 & 0.03322900 & $\mathrm{a}$ \\
& 4 & 6 & $0.00833333 * *$ & 0.02041241 & $\mathrm{a}$ \\
\hline
\end{tabular}

**Treatment with more antagonistic effect against $R$. solani. Treatments: $\mathrm{T} 1=10 \mu \mathrm{L}, \mathrm{T} 2=100 \mu \mathrm{L}, \mathrm{T} 3=1000 \mu \mathrm{L}$, $\mathrm{T} 4=10000 \mu \mathrm{L}$ and $\mathrm{T} 5=$ Control; Rep= Replicates; $\mathrm{Ag}=$ Statistical aggrupation, equal letters are not statistically different according to Tukey test $(\mathrm{p}=0.05)$. 


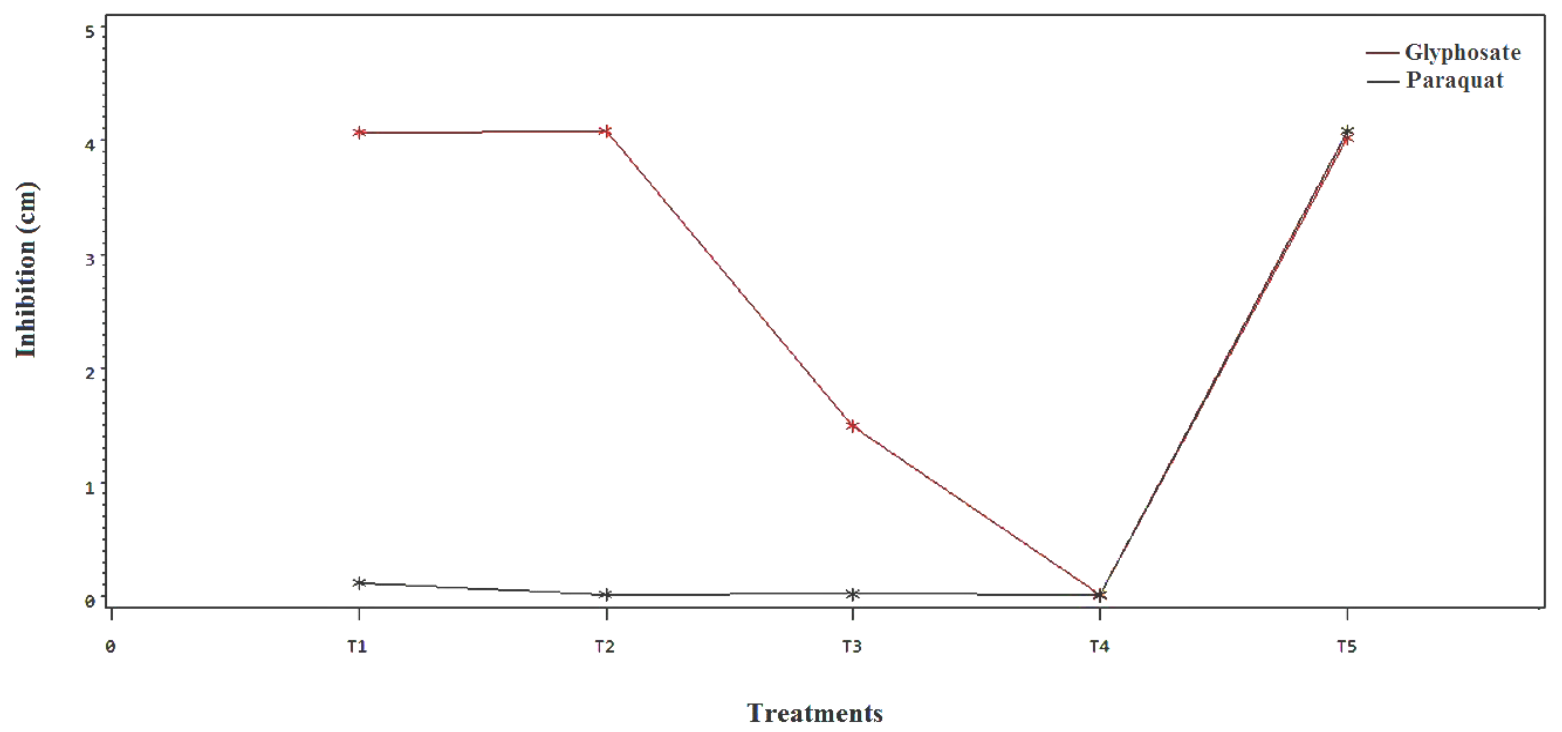

Figure 1. Inhibition of $R$. solani with the different treatments of paraquat and glyphosate. Treatments: $\mathrm{T} 1=10 \mu \mathrm{L}$, $\mathrm{T} 2=100 \mu \mathrm{L}, \mathrm{T} 3=1000 \mu \mathrm{L}, \mathrm{T} 4=10000 \mu \mathrm{L}$ and $\mathrm{T} 5=$ Control.

\section{Conclusions}

High concentrations of paraquat inhibits $R$. solani $(10000 \mu \mathrm{L})$.

Glyphosate does not affect $R$. solani mycelium development at low dosages (10 and $100 \mu \mathrm{L})$ and inhibits it at higher doses $(10000 \mu \mathrm{L})$.

\section{Acknowledgements}

The authors want to thank the Universidad Autonoma Agraria Antonio Narro for the support provided.

\section{Author Contributions}

JLAV organized the manuscript, wrote the manuscript and edited it, and contributed to the application of statistical techniques. ASA conceptualized and formulated the general objectives of the research. MaEGC supervised the execution of research activities. CTR responsible for preservation of data, and annotations in the investigation.

\section{References}

Abd-Elsalam, K. A., Moslem, M. A., \& Bahkali, A. H. (2009). First morpho-molecular identification of Rhizoctonia solani AG-7 from potato tuber-borne sclerotium in Saudi Arabia. African Journal of Microbiology Research, 3(12), 952-956.

Agrios, G. N. (2004). Plant Pathology (5a ed.). San Diego, California, Elsevier Academic Press.

Ajayi-Oyetunde, O. O., \& Bradley, C. A. (2016). Identification and Characterization of Rhizoctonia Species Associated with Soybean Seedling Disease. Plant Disease, 101, 520-533.

https://doi.org/10.1094/PDIS-06-16-0810-RE

Arellano-Aguilar, O., \& Von, O. J. R. (2016). La huella de los plaguicidas en México. https://doi.org/10.13140/RG.2.2.11406.36168

Bórtoli, P. V., Verdenelli, R. A., Conforto, C., Vargas, G. S., \& Meriles, M. J. (2012). Efectos del herbicida glifosato sobre la estructura y el funcionamiento de comunidades microbianas de dos suelos de plantaciones de olivo. Argentina. Ecología Austral, 22, 33-42.

Carling, D. E., Leiner, R. H., \& Wesrphale, P. C. (1989). Symptoms, signs and yield reduction associated with Rhizoctonia disease of potato induced by tuberborne inoculum of Rhizoctonia solani AG-3. American Potato Journal, 66, 693-701. https://doi.org/10.1007/BF02896825

Carling, D. E., Rothrock, C. S., Macnish, G. C., Sweetingham, M. W., Brainard, K. A., \& Winter, S. W. (1994). Characterization of anastomosis group 11 (AG11) of Rhizoctonia solani. Phytopathology, 84, 1387-1393. https://doi.org/10.1094/Phyto-84-1387 
Carling, D. E., Pope, E. J., Brainard, K. A., \& Carter, D. A. (1999). Characterization of mycorrhizal isolates of Rhizoctonia solani from an orchard, including AG-12, a new anastomosis group. Phytopathology, 89, 942-946. https://doi.org/10.1094/PHYTO.1999.89.10.942

Carling, D. E., Pope, E., Brainard, K., \& Carter, D. (1999). Characterization of mycorrhizal isolates of Rhizoctonia solani from an orchid, including AG-12, a new anastomosis group. Phytopath., 64, 492-496. https://doi.org/10.1094/PHYTO.1999.89.10.942

Carling, D. E., Baird, R. E., Gitaitis, R. D., Brainard, K. A., \& Kuninaga, S. (2002). Characterization of AG-13, a newly reported anastomosis group of Rhizoctonia solani. Phytopathology, 92, 893-899. https://doi.org/10.1094/PHYTO.2002.92.8.893

Carrera, M. F., \& Carreras, H. A. (2011). Efectos de la aplicación de glifosato sobre parámetros químicofisiológicos en Usnea amblyoclada (M üll. Arg.) Zahlbr. Argentina. Ecología Austral, 21, 353-361.

Castaño, Z. J. (1986). Efecto de cuatro herbicidas y un fungicida sobre el crecimiento de Rhizoctonia solani kuhn en condiciones de laboratorio. Honduras. Revista Ceiba, 27, 1-5. Retrieved from https://bdigital.zamorano.edu/handle/11036/3894

Cedeño, L., Carrero, C., Quintero, K. J., Araujo, Y., Pino, H., \& García, R. (2001). Identificación y virulencia de grupos de anastomosis de Rhizoctonia solani Kühn asociados con papa en Mérida, Venezuela. Interciencia, 26, 296-300.

Dhingra, O. D., \& Sinclair, J. B. (1985). Basic Plant Pathology Methods. Editorial CRC Press.

Díaz-Nájera, J., Vargas-Hernández, M., Ayvar-Serna, S., Alvarado-Gómez, O., Solís-Aguilar, J., Durán-Ramírez, J., Díaz-Ceniceros, H., \& Hernández-Aguilar, A. (2014). Identificación morfológica y por pcr de Rhizoctonia solani kühn a partir de frutos de calabaza pipiana y su manejo en invernadero. Biotecnia, XVI(3),17-21. https://doi.org/10.18633/bt.v16i3.107

Duke, S. O. (2018). The history and current status of glyphosate. Pest. Manag. Sci., 74, 1027-1034. https://doi.org/10.1002/ps.4652

Duke, S. O., \& Powles, S. B. (2008). Glyphosate-Resistant Weeds and Crops. Pest. Manag. Sci., 64, 317-318. https://doi.org/10.1002/ps.1561

Elsharkawy, M. M., Hassan, N., Villajuan-Abgona, R., \& Hyakumachi, M. (2014). Mechanism of biological control of Rhizoctonia damping-off of cucumber by a non-pathogenic isolate of binucleate Rhizoctonia. Afr. J. Biotechnol., 13, 640-650. https://doi.org/10.5897/AJB2013.13584

Food and Agriculture Organization of the United Nations (FAOSTAT). (2020). Food and agriculture data. Retrieved from http://www.fao.org/faostat/es/\#data

Franz, J. E., Mao, M. K., \& Sikorski, J. A. (1997). Glyphosate: a unique global herbicide. ACS Monograph 189, American Chemical Society, Washington, DC. https://doi.org/10.1017/S0890037X0004433X

Gareth, J. D., \& Williams, J. R. (197I). Effect of paraquat on growth and sporulation of Septoria nodorum and Septoria tritici. Trans. Brit. mycol. Soc., 57, 35I. https://doi.org/10.1016/s0007-1536(71)80021-9

Grosch, R., Koch, T., \& Kofoet, A. (2004). Control of bottom rot on lettuce caused by Rhizoctonia solani with commercial biocontrol agents and a novel fungicide. J. Plant Dis. and Protect, 111(6), 572-582.

Harikrishnan, R., \& Yang, X. B. (2001). YangInfluence of herbicides on growth and sclerotia production in Rhizoctonia solani. Weed Sci., 49, 241-247. https://doi.org/10.1614/0043-1745(2001)049[0241:IOHOGA]2.0.CO;2

Hernández, H. N. A., \& Martínez, M. A. (2006). Intoxicación por paraquat. Salud en Tabasco, 6(1), 302-305.

Hussain, T., Singh, B. P., \& Anwar, F. (2018). Soil Baiting, Rapid PCR Assay and Quantitative Real Time PCR to Diagnose Late Blight of Potato (Phytophthora infestans) in Quarantine programs. Journal of Nepal Agricultural Research Council, 4, 25-32. https://doi.org/10.3126/jnarc.v4i1.19687

International Union of Food, Agricultural, Hotel, Restaurant, Catering, Tobacco and Allied Workers Associations (UITA). (2020). La Noria de Roundup, la OMS y kupoteza plaguicidas. Retrieved from https://iuf.org/sw/la-noria-de-roundup-la-oms-y-los-plaguicidas/

James, C., \& Krattiger, A. F. (1996). Global review of the field-testing and commercialization of transgenic plants, 1986-1995: The first decade of crop biotechnology. ISAAA Briefs No. 1, ISAAA, Ithaca, NY. p. 31. Retrieved from https://www.isaaa.org/search/default.asp 
Katan, J., \& Eshel, Y. (1973). Interactions between herbicides and plant pathogens. Residue Rev., 45, 145-177. https://doi.org/10.1007/978-1-4615-8493-3_5

Mensin, S., Soytong, K., McGovern, R. J., \& To-anun, C. (2013). Effect of agricultural pesticides on the growth and sporulation of nematophagous fungi. Journal of Agricultural Technology, 9, 953-961.

Meza-Moller, A., Esqueda, M., Gardea, A., Tiznado, M., \& Virgen, C. G. (2007). Variabilidad morfológica, patogénica y susceptibilidad a fungicidas de Rhizoctonia solani aislado de rizósfera de Vitis vinifera var. perlette seedless. Revista Mexicana de Micología, 24, 1-7. https://doi.org/10.33885/sf.2007.3.987

Misawa, T., Kurose, D., Mori, M., \& Toda, T. (2018). Characterization of Japanese Rhizoctonia solani AG-2-1 isolates using rDNA-ITS sequences, culture morphology, and growth temperature. Journal of General Plant Pathology, 84, 387-394. https://doi.org/10.1007/s10327-018-0808-1

Montealegre, J. R., Reyes, R., Pérez, L. M., Herrera, R., Silva, P., \& Besoain, X. (2003). Selection of bioantagonistic bacteria to be used in biological control of Rhizoctonia solani in tomato. Electronic Journal of Biotechnology, 6(2), 115-127. https://doi.org/10.4067/S0717-34582003000200006

Morjan, W. E., Pedigo, L. P., \& Lewis, L. C. (2002). Fungicidal effects of glyphosate and glyphosate formulations on four species of entomopathogenic fungi. Environ. Entomol., 31(6), 1206-1212. https://doi.org/10.1603/0046-225X-31.6.1206

Nicoletti, R., Lahoz, E., Kanematsu, S., Naito, S., \& Contillo, R. (1999). Caracterización de aislados de Rhizoctonia solani de campos de tabaco relacionados con los grupos de anastomosis 2-1 y BI (AG 2-1 y AG BI). Revista de fitopatología, 147, 71-77. https://doi.org/10.1046/j.1439-0434.1999.147002071.x

Nikraftar, F., Taheri, P., Falahati, R. M., \& Tarighi, S. (2013). Tomato partial resistance to Rhizoctonia solani involves antioxidative defense mechanisms. Physiol. Mol. Plant Pathol., 81, 74-83. https://doi.org/10.1016/j.pmpp.2012.11.004

Ogoshi, A. (1976). Studies on the grouping of Rhizoctonia solani Kuhn with hyphal anastomosis and on the perfect stages of groups. Bull. Natl. Inst. Agric. Sci. Ser. C., 30, 1-63.

Salazar-López, N. J., \& Aldana, M. M. L. (2011). Herbicida glifosato: usos, toxicidad y regulación. Revista de Ciencias Biológicas y de la Salud. Biotecnia, XIII(2), 23-28. https://doi.org/10.18633/bt.v13i2.83

SAS Institute. (2002). The SAS System for Windows, Release 9.1. SAS. Institute, Cary N. C. U.S.A.

Sistema Nacional de Información e Integración de Mercados (SNIIM). (2020). Insumos agrícolas. Retrieved from http://www.economia-sniim.gob.mx/Nuevo/Home.aspx?opcion=Consultas/MercadosNacionales/PreciosDe Mercado/Agricolas/ConsultaInsumos.aspx?SubOpcion=9|0\%20\%202019

Sneh, B. L., Burpee, L., \& Ogoshi, A. (1991). Identification of Rhizoctonia species. American Phytopatological Society, St. Paul, Minnesota, USA.

Vargas, A. A., Fuentes, L. C., \& Torres, T. E. (2002). Respuesta al glifosato de un aislamiento de Rhizoctonia solani. Agente causal del anublo de la vaina del arroz, y de cuatro aislamientos de Trichoderma, bajo condiciones in vitro. Agronomía Colombiana, 19(1-2), 43-55.

Vila-Aiub, M. M., Vidal, R. A., Balbi, M. C., Gundel, P. E., Trucco, F., \& Ghersa, C. M. (2008). Glyphosate-resistant weeds of South American cropping systems: an overview. Pest. Manag. Sci., 64(4), 366-71. https://doi.org/10.1002/ps.1488

Wilkinson, V., \& Lucas, R. L. (I969a). Effects of herbicides on the growth of soil fungi. New Phytol., 68, 709-719. https://doi.org/10.1111/j.1469-8137.1969.tb06475.x

Wilkinson, V., \& Lucas, R. L. (i969b). Effects of constituents of Gramoxone on rates of respiration of soil fungi. Weed Research, 9, 288-295. https://doi.org/10.1111/j.1365-3180.1969.tb01487.x

Wilkinson, V., \& Lucas, R. L. (I969c). Graxoxone W: its effect on spores and mycelia of Rhizopus stolonifer. Trans. Brit. mycol. Soc., 53, 297-299. https://doi.org/10.1016/S0007-1536(69)80064-1

Wilson, P., Ketola, O., Ahvenniemi, P. M., Lehtonen, M. J., \& Valkonenplant, J. (2007). Dynamics of soil borne Rhizoctonia solani in the presence of Trichoderma harzianum: effects on stem canker, black scurf and progeny tubers of potato. Pathology, 57(1), 152-16. https://doi.org/10.1111/j.1365-3059.2007.01706.x

Woodburn, A. T. (2000). Glyphosate: production, pricing and use worldwide. Pest. Manag. Sci., 56, 309-312. https://doi.org/10.1002/(SICI)1526-4998(200004)56:4<309::AID-PS143>3.0.CO;2-C

World Health Organization (WHO). (2020). Pesticide residues in food. Retrieved from 
https://www.who.int/news-room/fact-sheets/detail/pesticide-residues-in-food

\section{Copyrights}

Copyright for this article is retained by the author(s), with first publication rights granted to the journal.

This is an open-access article distributed under the terms and conditions of the Creative Commons Attribution license (http://creativecommons.org/licenses/by/4.0/). 